\title{
Practical Review of Diagnosis and Management of Cutaneous Tuberculosis in Indonesia
}

\author{
Tiffany Roelan
}

\section{ABSTRACT}

Tuberculosis is a life-threatening infectious disease that remains a high incidence worldwide. The classification of tuberculosis can be divided into two forms, i.e., pulmonary and extrapulmonary. The pathogenesis of tuberculosis depends on the cell-mediated immunity of the host. One of the variants of extrapulmonary tuberculosis is cutaneous tuberculosis, that commonly found in Indonesia. Based on the bacterial load, cutaneous tuberculosis is divided into two types, multibacillary and paucibacillary tuberculosis. Diagnosis of cutaneous tuberculosis often requires specific investigations, such as histopathology, Ziehl-Neelsen staining, InterferonGamma Release Assays, enzyme-linked immunosorbent assay serology, and Polymerase Chain Reaction. The treatment principle for cutaneous tuberculosis is the same as the treatment for pulmonary tuberculosis, which consists of an intensive and maintenance phase.

Keywords: Cutaneous tuberculosis, mycobacterium tuberculosis, skin, infection, extrapulmonary.

Submitted: September 4, 2021

Published: September 27, 2021

ISSN: 2593-8339

DOI: $10.24018 /$ ejmed.2021.3.5.1042

\section{T. Roelan*}

Dik Pusdikkes Kodiklat Indonesian Army Hospital, Jakarta, Indonesia (e-mail: roelantiffany@gmail.com)

*Corresponding Author

\section{INTRODUCTION}

Tuberculosis (TB) is a life-threatening bacterial infectious disease with a high incidence worldwide [1]. In addition, the development of new cases and resistant TB continues to increase by more than $60 \%$ of the general population in developed regions of India, South Africa, and Asia, including Indonesia [2], [3]. The clinical manifestations of TB can be divided into two, pulmonary (lung) TB and extrapulmonary TB (brain parenchyma, pericardium, abdominal organs, skin, and others) [4]. World Health Organization (WHO) reports that almost one-fifth of TB cases are extrapulmonary TB, predominantly demonstrated as cutaneous TB [2].

Cutaneous TB often presents with various atypical morphological features resembling other skin diseases [5]. The incidence of lupus vulgaris and verrucous TB is the highest type of cutaneous TB, affecting about $4.76 \%$ of TB patients in Indonesia. The causative agents of cutaneous TB in Indonesia are primarily due to Mycobacterium tuberculosis (M.TB) and Mycobacterium atypical [5]-[7].

Currently, TB eradication is still a burden for both patients and health workers. The increasing number of cutaneous TB cases in various places is caused by multiple factors, including incorrect diagnosis, inadequate treatment, and complex histopathological or supporting diagnostic features from various health facilities [8]. This literature review helps to understand the practical approach regarding the diagnosis and therapy of cutaneous TB, especially in the TB endemic country of Indonesia.

\section{Microbiology OF MYCOBACTERIUM TUBERCULOSIS}

Mycobacterium tuberculosis (M.TB) was first discovered by Robert Koch in 1882, along with its various bacterial species such as $M$. tuberculosis, $M$. africanum, $M$. bovis, $M$. canetti, M. microti [9]. Mycobacterium tuberculosis belongs to the Schizomycetes class, Mycobacteriaceae (Grampositive) family, and genus Mycobacterium. This organism has an obligate intracellular pathogenic pattern that can infect humans. It is described as a non-motile bacterium, which does not contain capsules or form endospores, and is aerobic; thus, it requires oxygen to reproduce. In addition, these bacteria have cell walls-containing lipids that are resistant to alcohol staining and have acid-fastness properties; therefore, the acidfast bacilli (AFB) test is often used to identify the presence of M.TB [10]. The course of M.TB disease depends on the level of virulence and the host's immune response [11].

\section{Pathogenesis of Cutaneous Tuberculosis}

The pathogenesis of M.TB depends on the complex interactions between the pathogen and the host cell-mediated immunity. Each classification of cutaneous TB comes with different transmission characteristics; among others, it can infect through the air from lung-TB infected nearby person to others and the spread hematogenously, via direct inoculation (skin contact with TB infected person), or through transplacental transmission [9]. The transmission of M.TB to humans initiates host cell-mediated immunity to activate macrophage cells that play a role in phagocytosis and will later circulate to the lymph nodes and target organ tissue [12]. 
Macrophages also act as antigen-presenting cells (APCs) that will interact with $\mathrm{T}$ lymphocytes. $\mathrm{T}$ lymphocyte cells will serve as the "memory cell" against the pathogen for three to ten weeks, which will then circulate systemically or to the affected target organ, causing the development of symptoms [12], [13].

\section{Classification of Cutaneous Tuberculosis}

Based on the number of bacteria present or the "bacterial load," cutaneous TB is divided into two types, i.e., the multibacillary (Scrofuloderma and Tuberculous gumma) usually AFB is more easily found in lesions or exudate; and the paucibacillary type (tuberculosis verrucosa, lupus vulgaris) [7], [10].

\begin{tabular}{ccc} 
TABLE I: CLASSIFICATION OF CUTANEOUS TUBERCULOSIS [7] \\
\hline \hline Exogenous & Endogenous & Hematogenous \\
Tuberculosis & Tuberculosis & Tuberculosis \\
\hline \hline Tuberculosis & Scrofuloderma & Lupus vulgaris \\
verrucosa & & $\begin{array}{c}\text { Tuberculous gumma } \\
\text { Tuberculoid }\end{array}$ \\
\hline \hline
\end{tabular}

\section{A. Tuberculosis Verrucosa}

Tuberculosis verrucosa cutis (TBVC) is a type of cutaneous TB that is often called prosector's wart of Laennec. It appears on the skin as a result of an immunologic reaction from exogenous inoculation or re-infection reactions from individuals who have been sensitized to M.TB [14]. Pathological manifestations usually appear in the predilection area of the hands, buttocks, and lower extremities. The lesions may be papules or papulopustular, which gradually enlarge to form verrucous plaques (Fig. 1). At first, these lesions are often misidentified as wart-like lesions [12]. However, a histopathological examination may reveal the pseudo-epitheliomatous hyperplasia of the epidermis and dermis with inflammatory infiltrates, including the neutrophils, lymphocytes, and giant cells [15].

A)

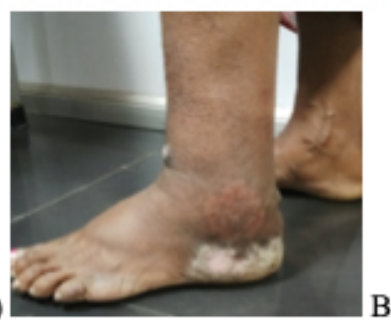

C)

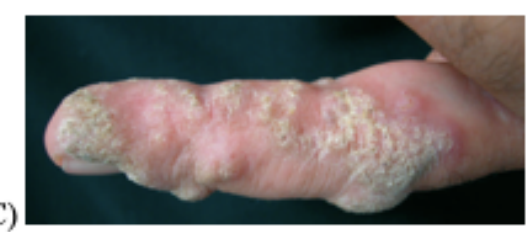

Fig. 1. Clinical manifestation of tuberculosis verrucosa; A) hyperpigmented plaque with a depigmented middle and verrucose surface on the left foot;

B) verrucose on the wrist; C) verrucosa erythema on the third finger.

\section{B. Scrofuloderma}

Tuberculosis cutis causes skin damage, particularly in the subcutaneous layer, which will progressively be affecting the lymph nodes; thus, later known as TB lymphadenitis or scrofuloderma (Fig. 2). Initially, M.TB will pass through the subcutaneous tissue, form mobile nodules, and invade deeper into the subcutaneous layer. Eventually, the nodule may develop into a cutaneous abscess but can heal spontaneously in a few months. Scrofuloderma is most often found among pediatric patients under ten years old, with a total prevalence of $36-48 \%$. However, scrofuloderma can also occur in patients with systemic TB, such as pulmonary $\mathrm{TB}$, which is often found in the axilla, colli, and thorax.

The initial clinical manifestations often begin with swelling or nodules, which subsequently turn firm on the surface and become abscess with several sinuses in it. The lesion may form a collection of purulent discharge ulcers. If ruptured, the lesion may develop into a deeper ulcer with histopathological findings of tissue necrosis, granulomas, and positive result on the acid-fast bacilli (AFB) staining [16].
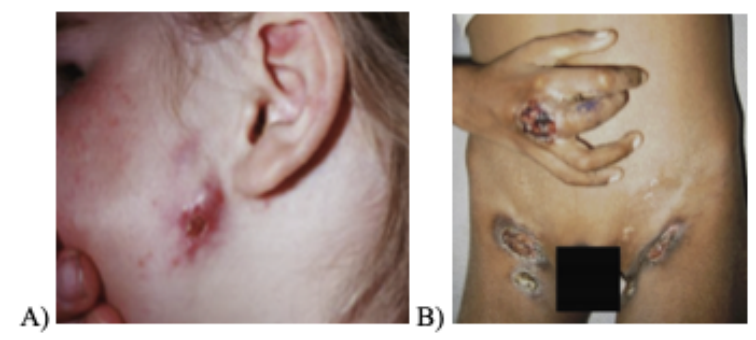

Fig. 2. Clinical manifestation of scrofuloderma; A) in children; B) lymphatic manifestation in adult patients [16].

\section{Lupus Vulgaris}

Some cases of cutaneous TB can occur due to the hematogenous spread of M.TB, which is commonly found in patients with chronic pulmonary $\mathrm{TB}$ or with inadequate therapy. Lupus vulgaris (LV) can also appear after Bacille Calmette-Guérin (BCG) vaccination or as the process of inoculation of TB germs primarily. Lupus vulgaris can be found in pediatric or adolescent patients. The pathological morphology includes skin hypertrophy, ulceration, papules or nodules, and plaques (most commonly found). The appearance of the plaque may grow and expand into reddishbrown papules, which slowly turn into thick scars and hyperkeratosis (Fig. 3). Sometimes the lesions turn into ulceration and other morphological features that are difficult to identify due to the dominant destructive process, and invasively become necrotic tissue then turn atrophic (crustlike scar). The vegetative appearance of the LV is presented as ulcerative and necrotic tissue with minimal scarring process, unless the lesion is located on the nasal and auricle region with a predominantly destructive appearance of scarring. Lupus vulgaris has a $10 \%$ risk of developing squamous cell carcinoma for 10-15 years [12].

A)
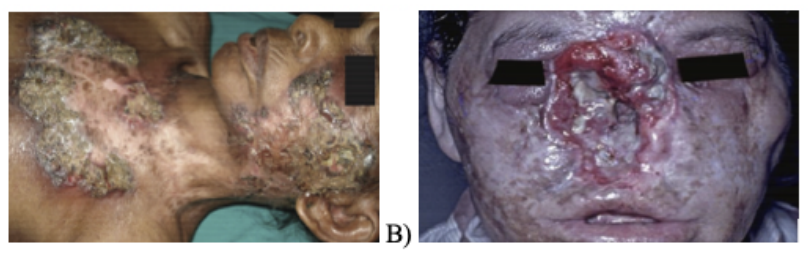

Fig. 3. A) Clinical manifestation of lupus vulgaris; B) deep ulceration in the nasal region [17]

\section{Tuberculous Gumma}

Tuberculous gumma is another variant of cutaneous TB that spreads hematogenously, with an incidence rate of $1-2 \%$. The pathological morphology manifests as a hard fixed 
nodule, which may rupture due to abscess formation and become necrotic tissue with an ulcerated appearance (Fig. 4). The pathogenesis is due to immunocompromised conditions with a high-level virulence of M.TB. The histopathological examination may find necrotic tissue in the tubercles with a positive smear. In immunocompetent patients, the lesions often resolve spontaneously [17].

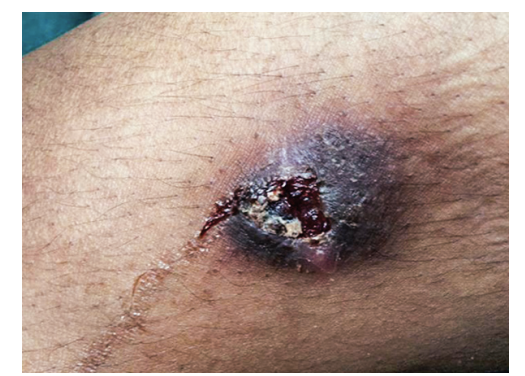

Fig. 4. A) Clinical manifestation of tuberculous gumma in the right limb of a patient with pulmonary TB [17].

\section{E. Tuberculoid leprosy}

Darier first discovered the concept of tuberculoid in 1896. Tuberculoid is a type of cutaneous TB formed due to the host's immunological reaction to M.TB or immunological excessive response [17]. Some examples of tuberculoid are papulonecrotic tuberculoid, erythema induratum or Bazin disease, and lichen scrofulosorum or tuberculosis cutis lichenoides (Fig. 5).

A)
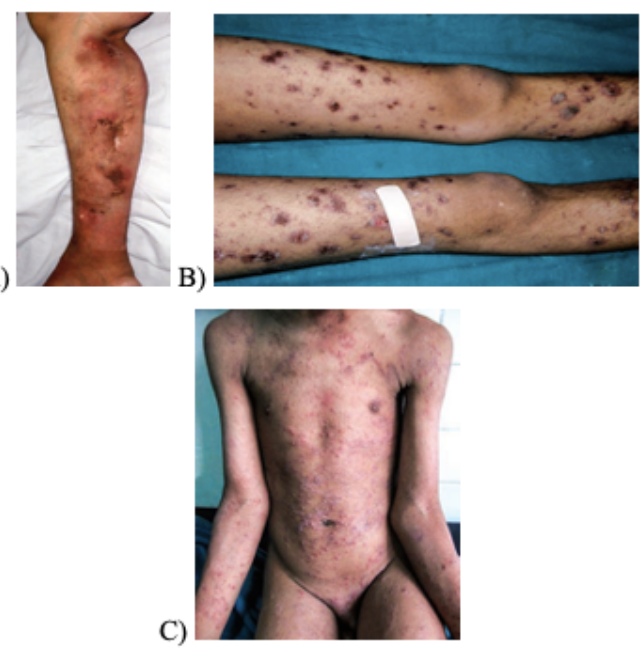

Fig. 5. A) Clinical manifestation of A) Erythema induratum or Bazin disease in the inferior extremity; B) Papulonecrotic tuberculoid in the inferior extremities; and C) Generalized lichen scrofulosorum in pulmonary TB patients [16],[17].

\section{F. Papulonecrotic tuberculid}

The most common clinical finding of papulonecrotic tuberculoid is usually found among pediatric patients with symmetrical lesions and recurrent eruptions with an erythematous, purple-colored papule-like morphology that develops into pustules with necrotic tissue. The predilection for lesions most often appears on the face, thorax, buttocks, and lower extremities [18]. The cutaneous manifestations are often accompanied by systemic symptoms, including fever and weakness. Erupted skin lesions will spontaneously recover after weeks to months, leaving several depressed varioliform scar lesions. Administration of anti-tuberculosis drugs for a few days to weeks usually gives satisfactory results [10].

\section{G. Erythema Induratum (Bazin disease)}

Erythema induratum or Bazin disease is tuberculous granulomatous panniculitis due to M.TB. The most common predilection being the lower extremities, especially in the posterior region of the femur and inferior leg. It commonly affects young people and women. The lesion is very painful, manifested as a purplish-erythematous nodule that persists for several weeks without resolution. Nodules can sometimes become deep ulcers and produce secretions. Lesions may spontaneously resolve within months to years, without causing hyperpigmentation and scarring, but recurrence without treatment usually occurs within 3-4 months after the lesions have disappeared [10].

\section{H. Lichen scrofulosorum}

Lichen scrofulosorum is a type of Tuberculoid leprosy that is rarely found and usually appears in the presence of systemic comorbidities, such as bone TB. The morphology of the lesions is usually clusters of plaques, which are asymptomatic; or follicular or perifollicular papules that are reddish-yellow to reddish-brown. The common predilection is mostly found in the thorax region. The administration of anti-tuberculosis drugs in the first week usually gives an excellent therapeutic effect with a resolution of the lesions without scarring the skin. However, even without the drugs, the lesions may disappear for several years [10].

Some cases of atypical cutaneous TB often require further investigations, such as histopathological examination and Polymerase Chain Reaction (PCR), to confirm the diagnosis [15]. Borretta et al. reported that atypical cutaneous TB often occurs in post-traumatic patients with chronic wounds. The presence of chronic wounds without recovery should raise the suspicion of atypical cutaneous TB; thus, a histopathological examination may be considered [19].

\section{SUPPORTING EXAMINATION}

Diagnostic establishment of cutaneous TB often requires several investigations, such as histopathological examination with common findings of tuberculoid granuloma with lymphocytes. These findings often vary because it depends on the severity of cutaneous TB and immunological reactions in patients according to the classification of cutaneous TB (Table II). Ziehl-Neelsen staining examination is frequently used to identify the AFB from M.TB pathogen (Fig. 6) [20].

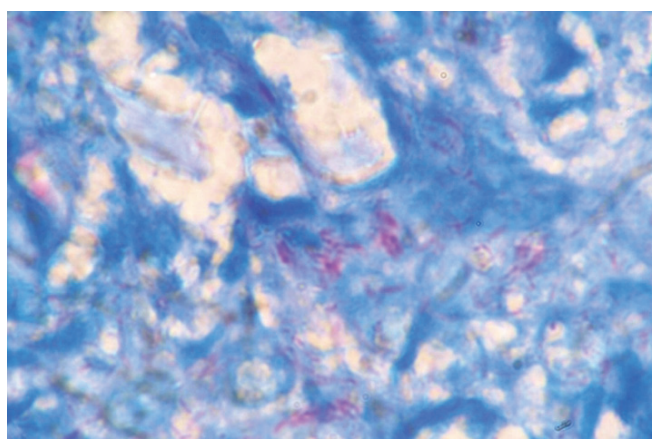

Fig. 6. Ziehl-Neelsen staining with positive acid-fast bacilli (AFB). 
Polymerase Chain Reaction can also be considered to identify deoxyribonucleic acid (DNA) of M.TB bacteria [20]. Agarwal et al. reported that histopathological examination, culture, and DNA PCR sensitivity values are 91.8\%, 16.3\%, and $24.5 \%$, respectively. On the other hand, Raj et al. [21] found that DNA PCR portrayed a sensitivity of $96 \%$ and a specificity of $100 \%$. Therefore, this examination can be considered for cutaneous TB that cannot be identified by culture or histopathological examinations, which is highly dependent on the host immune response [21].

TABLE II: HiSTOPATHOLOGICAL FINDINGS BASED ON THE CLASSIFICATION OF CUTANEOUS TUBERCULOSIS [22]

\begin{tabular}{|c|c|c|}
\hline Cutaneous TB & Histopathological Findings & AFB Finding \\
\hline Tuberculosis & Pseudo-epitheliomatous & \\
\hline Verrucosa & $\begin{array}{l}\text { hyperplasia of the epidermis } \\
\text { with hyperkeratosis and } \\
\text { neutrophil infiltrate, giant } \\
\text { cells, and granulomatous } \\
\text { infiltrate (Cardinal sign) }\end{array}$ & $(+)$ \\
\hline Scrofuloderma & $\begin{array}{l}\text { Massive central necrotic } \\
\text { appearance with abscess, } \\
\text { granuloma on the periphery } \\
\text { of the lesion }\end{array}$ & $(+)$ \\
\hline Lupus vulgaris & $\begin{array}{l}\text { Epidermal atrophy or } \\
\text { hypertrophy with acanthosis, } \\
\text { papillomatosis, pseudo- } \\
\text { epitheliomatous hyperplasia, } \\
\text { Langhans giant cells, } \\
\text { granulomas in the dermis }\end{array}$ & $(+)$ \\
\hline Tuberculous Gumma & $\begin{array}{c}\text { Central ulceration with } \\
\text { caseous necrosis surrounded } \\
\text { by giant cells and } \\
\text { macrophages }\end{array}$ & $(+)$ \\
\hline $\begin{array}{l}\text { Tuberculoid leprosy } \\
\text { - Papulonecrotic }\end{array}$ & $\begin{array}{l}\text { Epidermal psoriasiform } \\
\text { hyperplasia and epithelioid } \\
\text { granuloma with lymphocytes } \\
\text { and giant Langhans cells } \\
\text { mixed with necrotic tissue in } \\
\text { the upper and mid dermis } \\
\text { with a perifollicular } \\
\text { distribution. }\end{array}$ & $(-)$ \\
\hline $\begin{array}{l}\text { - Lichen } \\
\text { skrofulosorum }\end{array}$ & $\begin{array}{l}\text { Epithelioid granuloma cell } \\
\text { appearance in the upper } \\
\text { dermis and around the } \\
\text { dermal appendages }\end{array}$ & $(-)$ \\
\hline
\end{tabular}

\section{DiAgnOSIS}

Establishing a clinical diagnosis of cutaneous TB should be done carefully and sometimes requiring several other tests to confirm an accurate diagnosis, such as a biopsy and AFB examination. Human immunodeficiency virus (HIV) screening is also necessary to suspect patients with an immunocompromised state. The findings of a positive Mantoux test ( $>15 \mathrm{~mm}$ ) provides a high diagnostic value, but a negative result also cannot exclude the possibility of cutaneous TB. Sultana et al. [23] reported positive results in the Mantoux test in pediatric patients with clinical features of scrofuloderma $(63.6 \%)$, lupus vulgaris $(62.5 \%)$, and TB verrucosa (100\%). Interferon-Gamma Release Assays (IGRA), enzyme-linked immunosorbent assay (ELISA) serology, and PCR, have a definite role in diagnosing cutaneous TB. Still, these tests are not routinely performed because of the high cost. In general, all patients who have a suspicion of cutaneous TB should be screened initially with a chest x-ray and sputum smear examination to rule out pulmonary $\mathrm{TB}$, followed by contact tracing, especially in pediatric patients [24].

\section{MANAGEMENT}

The principle of cutaneous TB treatment is generally the same as the treatment of pulmonary tuberculosis [25]. Based on the Indonesian Society of Dermatology and Venereology, the main treatments are divided into two types, i.e., topical, and systemic therapy [26].

\section{A. Topical}

The topical management of cutaneous TB is mainly performed to treat pathological skin conditions, including ulcerations. In addition, skin compresses with an antiseptic solution (povidone-iodine 1\%) can be given to prevent further infection to the skin structure [26].

\section{B. Systemic}

Systemic anti-tuberculosis drug therapy is categorized into an intensive phase and a continuation phase. At the initial phase, the combination of isoniazid (Isonicotinic Acid Hydrazide (INH) $400 \mathrm{mg} /$ day, rifampin (R) $600 \mathrm{mg} /$ day, and ethambutol (E) $1000 \mathrm{mg} /$ day are given for two to three months. The next three months are followed by the continuation phase with the administration of INH $400 \mathrm{mg}$, rifampin $600 \mathrm{mg}$, and pyridoxine (vitamin B6) $10 \mathrm{mg}$ three times a week for up to six months [26]. Gavazzoni et al. [27] classified several regimens of fixed-dose combination drugs for adult patients or patients with age over ten years old and patients under ten years old with cutaneous TB (Tables III and IV). In patients under five years of age with difficulty administering tablet preparations, the drug should be given in syrup preparations ( 1 hour before meals or 2 hours after meals) [27].

Treatment of cutaneous TB is administered for six months regardless of the presence of other co-infections. Administration of pyridoxine is recommended to prevent peripheral neuropathy [24]. Particular attention should be given to patients over 60 years of age with impaired toxicity during treatment with anti-tuberculosis drugs [22]. In patients with hepatic impairment, serial liver enzyme tests are required [23] Yasaratne et al. [24] stated that all cutaneous TB patients taking anti-tuberculosis drugs should have serial examinations to determine the presence of major and minor side effects of the drugs, including visual disturbances, druginduced hepatitis, cholestasis, and thrombocytopenia.

\section{PREVENTION}

The administration of the BCG vaccine is an important preventive measure in reducing the incidence of extrapulmonary TB. A significant reduction of cutaneous TB is found among vaccinated populations [17]. In addition, early diagnosis and appropriate treatment of pulmonary TB patients can reduce the transmission through minor skin injuries or abrasions that can become M.TB port de-entre. Clinicians also play an essential role in health promotion regarding a healthy lifestyle and balanced nutrition [17]. 
TABLE III: ANTI-TUBERCULOSIS REGIMENTS PATTERN (2RHZE/4RH) IN ADULT AND PEDIATRIC PATIENTS (> 10 YEARS) FOR ALL TYPES OF CUTANEOUS TB, WITH OR WITHOUT HIV [27]

\begin{tabular}{|c|c|c|c|c|}
\hline Regiment Phase & Medication & "Body Weight & Dosage & Medication Period \\
\hline $\begin{array}{c}2 \text { RHZE } \\
\text { Intensive Phase }\end{array}$ & $\begin{array}{c}\text { RHZE } \\
150 / 75 / 400 / 275^{*}\end{array}$ & $\begin{array}{l}20 \mathrm{~kg}-35 \mathrm{~kg} \\
36 \mathrm{~kg}-50 \mathrm{~kg} \\
\quad>50 \mathrm{Kg}\end{array}$ & $\begin{array}{l}2 \text { tablets } \\
3 \text { tablets } \\
4 \text { tablets }\end{array}$ & 2 months \\
\hline $\begin{array}{c}4 \mathrm{RH} \\
\text { Continuation Phase }\end{array}$ & $\begin{array}{c}\text { RH } \\
300 / 300 \text { or } 150 / 100 \\
\text { or } 150 / 75\end{array}$ & $\begin{array}{l}20 \mathrm{~kg}-35 \mathrm{~kg} \\
36 \mathrm{~kg}-50 \mathrm{~kg} \\
\quad>50 \mathrm{~kg}\end{array}$ & $\begin{array}{c}1 \text { tablet } 300 / 200 \mathrm{mg} \text { or } 2 \text { tablets } 150 / 75 \\
1 \text { tablet } 300 / 200 \mathrm{mg}+1 \text { tablet } 150 / 100 \text { or } 3 \text { tablets } 150 / 75 \\
2 \text { tablets } 300 / 200 \mathrm{mg} \text { or } 4 \text { tablets } 150 / 75\end{array}$ & 4 months \\
\hline
\end{tabular}

*Fixed-dose combination drug; R, Rifampicin; H, Isoniazid; Z, Pyrazinamide; E, Ethambutol.

TABLE IV: ANTI-TUBERCULOSIS REgIMENTS PATTERN (2RHZ/4RH) IN PEDIATRIC PATIENTS ( $<10$ YEARS) FOR ALL TYPES OF CUTANEOUS TB, WITH OR WITHOUT HIV [27]

\begin{tabular}{|c|c|c|c|c|c|}
\hline \multirow{2}{*}{ Regiment Phase } & \multirow{2}{*}{ Medication } & \multicolumn{4}{|c|}{ Body Weight } \\
\hline & & $>20 \mathrm{~kg}(\mathrm{mg} / \mathrm{kg} /$ day $)$ & $>21 \mathrm{~kg}-35 \mathrm{~kg}$ (mg/ day) & $>36 \mathrm{~kg}-45 \mathrm{~kg}$ (mg/ day) & $>45 \mathrm{~kg}$ (mg/ day) \\
\hline & $\overline{\mathrm{R}}$ & 10 & 300 & 450 & 600 \\
\hline $2 \mathrm{RHZ}$ & $\mathrm{H}$ & 10 & 200 & 300 & 400 \\
\hline Intensive Phase & $\mathrm{Z}$ & 35 & 1000 & 1500 & 2000 \\
\hline $4 \mathrm{RH}$ & $\mathrm{R}$ & 10 & 300 & 450 & 600 \\
\hline Continuation Phase & $\mathrm{H}$ & 10 & 200 & 300 & 400 \\
\hline
\end{tabular}

R, Rifampicin; H, Isoniazid; Z, Pyrazinamide.

\section{Prognosis}

The role of anti-tuberculosis therapy in cutaneous TB patients provides satisfactory results if treatment is given early and for six months [22]-[26]. May et al. reported 103 cutaneous TB patients who were given anti-tuberculosis for six months in China; most patients presented with resolved scar lesions that thinned during therapy after the intensive phase [28]. However, nine patients underwent a change in regimen because of the side effects of the anti-tuberculosis drugs that could not be tolerated. Patients who have complaints of dominant anti-tuberculosis drugs side effects have a poor prognosis.

\section{Conclusion}

Tuberculosis cutis is a skin disease caused by Mycobacterium tuberculosis with classification based on the endogenous, exogenous, and hematogenous spread, which have different skin morphology and histopathological findings. The diagnosis of cutaneous tuberculosis requires a comprehensive history and physical examination with available investigations. Treatment of cutaneous tuberculosis is generally similar to the treatment of pulmonary $\mathrm{TB}$, which consists of intensive and continuous treatment phases. The prognosis is quite good if anti-tuberculosis drug therapy is given for six months.

\section{REFERENCES}

[1] A. Zumla, M. Raviglione, R. Hafner, C. F. von Reyn, "Tuberculosis," NEJM, vol. 368, no. 8, pp. 745-755, 2013.

[2] D. Resnawita, M. Rays, H. Iskandar, et al., "Laporan tiga kasus tuberculosis ekstra paru," Indonesia Journal Chest \& Critical Care Medical, vol. 5, no. 3, pp. 23-29, 2018.

[3] J. Nurman, D. B. Setyanto DB, "Skrofuloderma pada anak: penyakit yang terlupakan?," Sari Pediatri, vol. 12, no. 2, pp. 108-115, 2010.

[4] N. Noviarisa, F. F. Yani, D. Basir, "Tren kasus tuberculosis anak di RSUP Dr. M. Djamil Padang tahun 2014-2016," Jurnal Kesehatan Andalas, vol.8, no. 1, pp. 36-41, 2019.

[5] A. Djuanda, "Tuberkulosis Kutis" in Ilmu Kesehatan Kulit dan Kelamin, A. Djuanda, M. Hamzah, S. Aisah, editors, $5^{\text {th }}$ Ed. Jakarta: Fakultas Kedokteran Universitas Indonesia, pp. 64-72, 2007.

[6] N. Mohanty, B. B. Nayak, "Cutaneous tuberculosis," Med. J. DY Patil Univ., vol. 7, no. 1, pp. 53-55, 2014.
[7] M. Mathur, S. N. Pander, "Clinicohistopatological profile of cutaneous tuberculosis in Central Nepal," Kathmandu Univ. Med. J., vol. 48, no. 4, pp. 238-241, 2014.

[8] M. Erawati, M. Andriany, "The prevalence and demographic risk factors for latent tuberculosis infection (LTBI) among healthcare workers in Semarang, Indonesia," Journal of Multidisciplinary Healthcare, vol. 13, pp. 197-206, 2020

[9] D. Sharma, D. Sarkar, "Pathophysiology of tuberculosis: an update review," PharmaTutor, vol. 6, no. 2, pp. 15-21, 2018.

[10] J. B. Santos, M. H. Oliveira, A. R. Figueiredo, et al., "Cutaneous tuberculosis: epidemiologic, etiopathogenic and clinical aspects," $A n$. Bras. Dermatol., vol. 89, no. 2, pp. 219-228, 2014.

[11] P. J. Cardona, "Pathogenesis of tuberculosis and other mycobacteriosis," Enferm. Infecc. Microbiol. Clin., vol. 36, no. 1, pp. $38-46,2018$.

[12] S. C. K. Ho, "Cutaneous tuberculosis: clinical features, diagnosis and management," H.K. Dermatol. Venereol. Bull., vol. 11, pp. 130-138, 2003.

[13] K. Sakamoto, "The pathology of mycobacterium tuberculosis infection," Veterinary Pathology, vol. 49, no. 3, pp. 423-439, 2012.

[14] C. Aliagaoglu, M. Atasoy, A. I. et al., "Tuberculosis verrucose cutis," Eur. J. Gen. Med., vol. 6, no. 4, pp. 268-273, 2009.

[15] D. Manjumeena, S. Sundaramoorthy, "Tuberculosis verrucose cutis masquerading as chromoblastomycosis - a case report," Our Dermatol. Online, pp. 275-278, 2018.

[16] M. K. Hill, C. V. Sanders, "Cutaneous tuberculosis," ASM Science, pp. $1-7,2017$.

[17] A. Singal, S. Sonthalia, "Cutaneous tuberculosis," The Skin Clinic \& Research Centre, India, pp. 267-97, 2015.

[18] P. R. V. Karna, M. M. Rusyati, "Papulonecrotic tuberculoid: a case report," IJBS., vol. 4, no. 1, pp. 4-8, 2020.

[19] L. Borretta, P. Green, "An atypical presentation of lupus vulgaris," $C M A J$, vol. 189, no. 12, pp. 469, 2017.

[20] M. R. Lapausa, A. M. Saldana, A. N. Asensio, "Extrapulmonary tuberculosis: an overview," Rev. Esp. Sanid. Penit., vol. 17, pp. 3-11, 2015.

[21] A. Raj, N. Singh, K. B. Gupta, et al., "Comparative evaluation of several gene targets for designing a multiplex-PCR for an early diagnosis of extrapulmonary tuberculosis," Yonsei Med. J., vol. 57, no. 1, pp. 88-96, Jan 2016.

[22] P. Khadka, S. Koirala, J. Thapaliya, "Cutaneous tuberculosis: clinicopathologic arrays and diagnostic challenges," Dermatology Research and Practice, no. 7201973, pp.1-9, 2018.

[23] A. Sultana, M. S. I. Bhuiyan, A. Haque et al., "Pattern of cutaneous tuberculosis among children and adolescent," Bangladesh Med. Res. Counc. Bull., vol. 38, pp. 94-97, 2012.

[24] B. M. Yasaratne, D. M. Madegedara, "Tuberculosis of the skin," Journal of the Ceylon College of Physicians, vol. 41, pp. 83-88, 2010.

[25] R. Semaan, R. Traboulsi, S. Kanj, "Primary mycobacterium tuberculosis complex cutaneous infection: report of two cases and literature review," International Journal of Infectious Diseases, vol. 12, pp. 472-477, 2008.

[26] A. Hehanussa, T. Lawalata, A. Kartini, et al., "Diagnosis skrofuloderma dan tubekrulosis kutis verukosa pada seorang pasien," 
Berkala Ilmu Kesehatan Kulit \& Kelamin, vol. 22, no. 3, pp. 221-226, 2010.

[27] M. F. Dias, M. V. Quaresma, D. R. Azulay, et al., "Update on cutaneous tuberculosis," An. Bras. Dermatol., vol. 89, no. 6, pp. 925938, 2014.

[28] Y. Mei, W. Zhang, Y. Shi, et al., "Cutaneous tuberculosis and nontuberculous mycobacterial infections at a National Specialized Hospital in China," Acta. Derm. Venereol., vol. 99, pp. 997-1003, 2019. 